doi: 10.32620/oikit.2020.89.05

УДК 621.9.031

О. В. Сагалович, В. В. Сагалович, В. В. Попов, С. Ф. Дуднік, О. В. Кононихін

\title{
Застосування іонно-плазмових методів для отримання тонкоплівкових паливних елементів
}

\begin{abstract}
Акціонерне товариство «ФЕД»
Нові вимоги до експлуатаційних систем літальних апаратів, поряд із постійно зростаючим тиском на зменшення споживання палива, забруднюючих речовин та викидів шуму, суттєво сприяють пошуку нових та більш чистих технологій, паливні елементи яких демонструють великий потенціал. В роботі показано досягнутий рівень розробок тонкоплівкових композиційних матеріалів з використанням іонно-плазмових і плазмохімічних методів на АТ «ФЕД», що створює передумови зміни властивостей по відношенню до традиційних матеріалів на 2...3 і більше порядків, зниження робочої температури до $400 \ldots 600^{\circ} \mathrm{C}$. Це дає змогу розробляти принципово нові конструкції тонкоплівкових паливних елементів (товщиною в 10-20 разів менше, ніж трубчастий варіант) і серійноздатні технології їх виготовлення в наступних напрямках: нанесення тонкоплівкових композицій на розроблену конструкцію з урахуванням технологічних обмежень для різних методів осадження; отримання композиційних матеріалів, що складаються з шарів: газощільного електроліту і електродних шарів з тонкоплівковими струмознімальними контактами; забезпечення поділу газових сумішей керамічним шаром електроліту при товщині < 50...20 мкм; мінімізація товщини плівкового електроліту та інших функціональних шарів паливної комірки; підвищення міцності зчеплення шарів і корозійної стійкості струмознімальних контактів і електродних шарів в робочих середовищах для забезпечення працездатності конструкції протягом всього процесу експлуатації.
\end{abstract}

Ключові слова: тонкоплівковий паливний елемент, іонно-плазмові методи, літак, електрична енергія.

\section{Вступ}

Нові вимоги до експлуатаційних систем літальних апаратів, поряд із постійно зростаючим тиском на зменшення споживання палива, забруднюючих речовин та викидів шуму, суттєво сприяють пошуку нових та більш чистих технологій, паливні елементи яких демонструють великий потенціал [1-3].

По мірі зростання попиту на електроенергію в польоті звичайні електрогенератори стали дуже великими. Отже, щоб пристосувати цю нову тенденцію, необхідно переосмислити виробництво енергії на борту літаків $[4,5]$.

Усвідомлюючи майбутнє використання паливних елементів у літаках (рис. 1), світова авіаційна промисловість активно створює робочі групи для розроблення керівних принципів використання систем паливних елементів для цивільних літаків [6, 7].

АТ «ФЕД» активно веде роботи в галузі застосування іонно-плазмових методів для отримання тонкоплівкових твердооксидних паливних елементів (SOFC), тому метою даної роботи $€$ показати досягнутий рівень розробок тонкоплівкових композиційних матеріалів з використанням іонно-плазмових і плазмохімічних методів. 


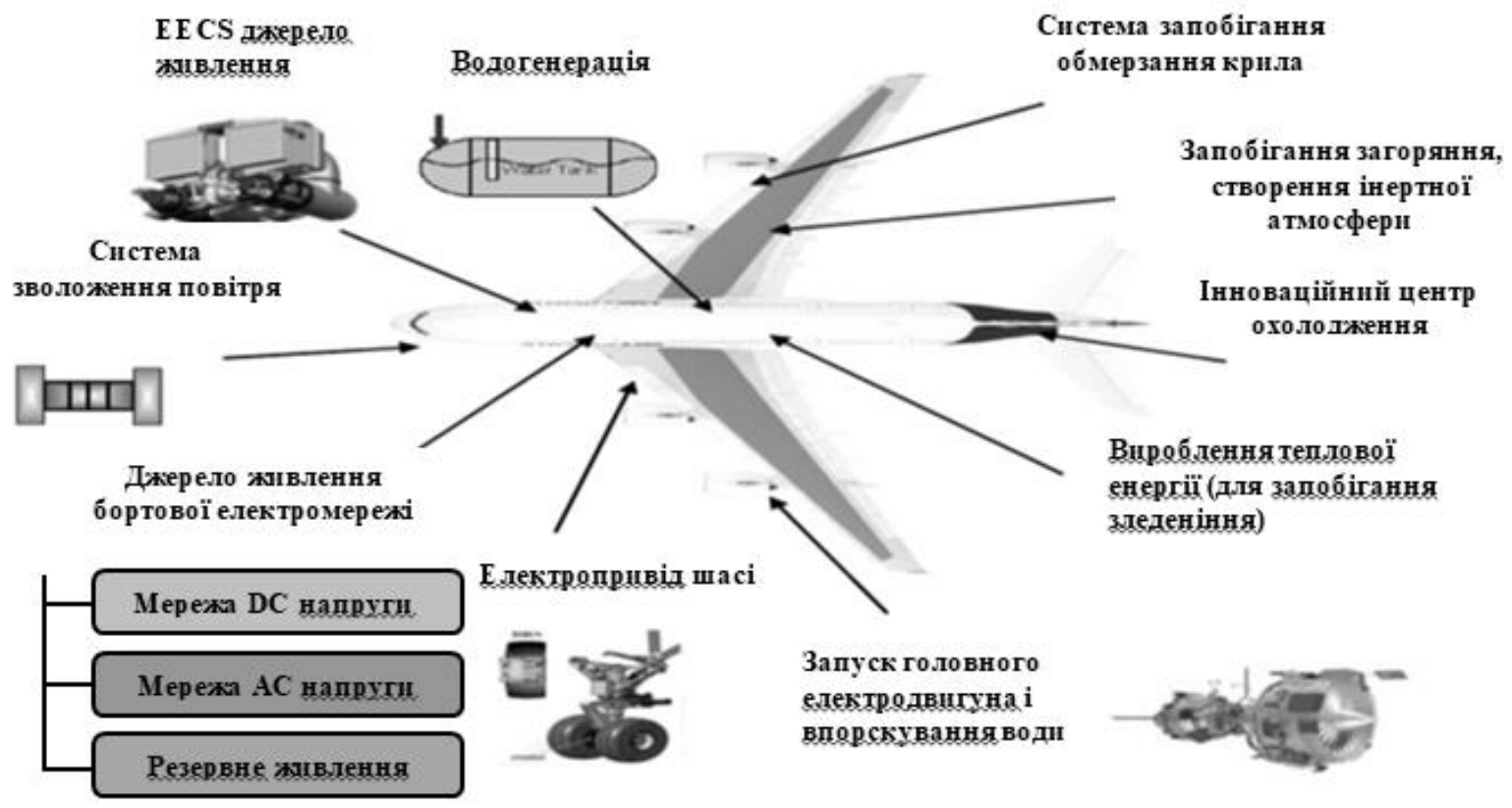

Рис. 1. Багатофункціональна система застосування паливних елементів на борту літака

\section{Основний матеріал}

Отримання електричної енергії традиційними способами забезпечується шляхом перетворення хімічної енергії в електричну через теплову (рис. 2a) і механічну енергію (рис. 2б).

Через значні втрати енергії при перетворенні тепла в механічну енергію ККД теплосилових установок дорівнює максимум $45 \%$, дизельних агрегатів $30 \%$ і бензинових агрегатів $20 \%$.

У разі прямого перетворення хімічної енергії в електричну за допомогою електрохімічних паливних елементів (рис. 2в) ККД принципово може досягати близько $80 \ldots 100 \%$. Тому цей спосіб відноситься до «високоефективних способів перетворення енергії»

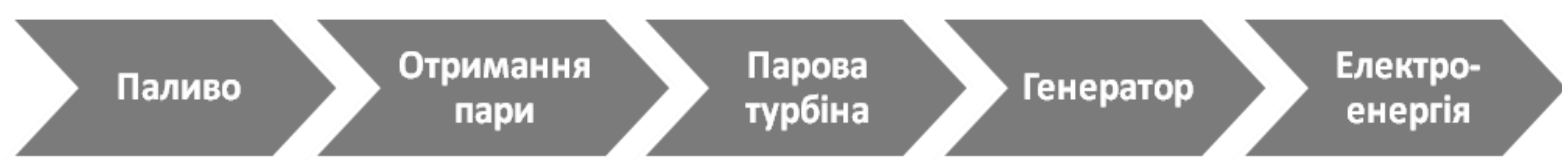

a

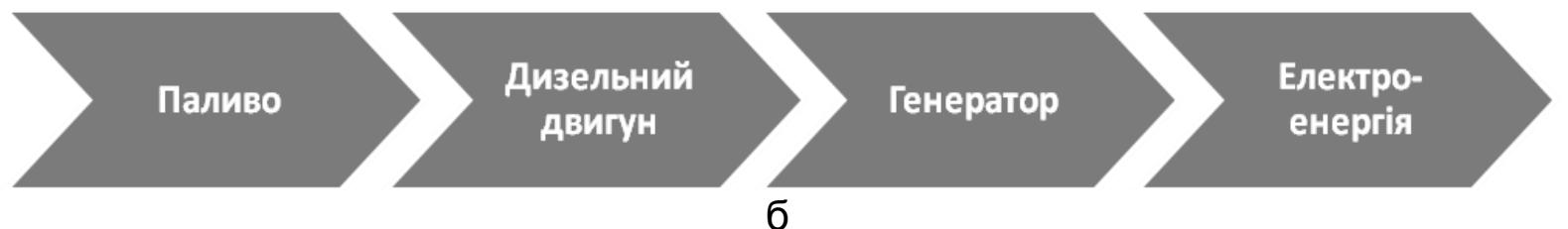

6

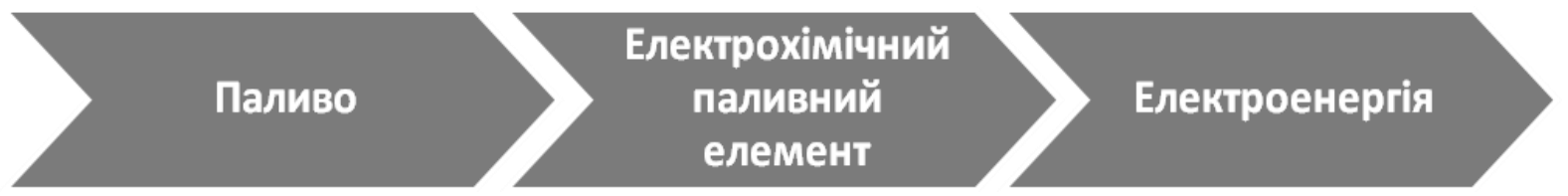

B

Рис. 2. Схеми отримання електричної енергії 
Найбільш перспективним напрямком підвищення ефективності паливних елементів (ПЕ) є зниження товщини складових PEN - структури з одночасною оптимізацією структурних характеристик.

Тонкоплівковим варіантом твердооксидних паливних елементів (рис. 3), безумовно, буде належати визначальне місце в майбутніх серійних конструкціях електрохімічних генераторів. Очевидні переваги тонкої плівки - зниження внутрішнього опору джерела і компактизація конструкції - незважаючи на складності реалізації.

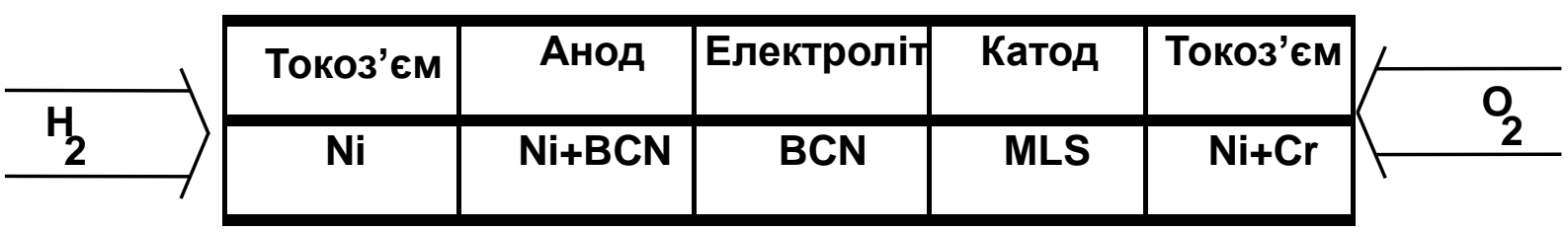

Рис. 3. Тонкоплівковий варіант твердооксидного паливного елемента

Схему шарів одиничного ПЕ з електролітом на основі цератів барію показано на рис. 4.

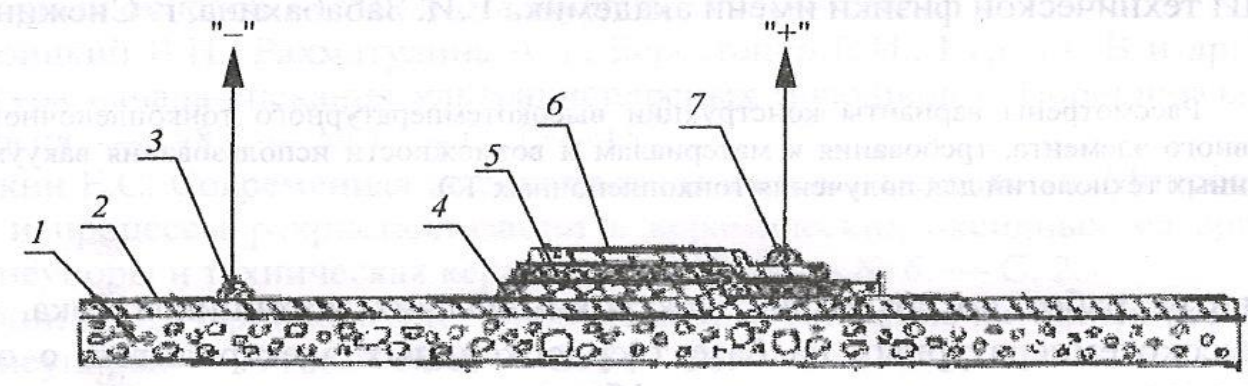

Рис. 4. Ескіз одиничного ПЕ: 1 - несуча основа; 2- струмознімання;

3, 7 - токовиводи; 4 - катод; 5 - твердий електроліт; 6 - анод.

Для плівкових ПЕ вакуум-плазмові методи фрормування композиції (електроліт - електрод - струмознімач) мають найбільш широкі можливості створення відповідних матеріалів з необхідним комплексом властивостей.

Найбільш прийнятними для нанесення тонких плівок електродних і електролітних багатокомпонентних оксидних матеріалів $€$ метод магнетронного розпилення та електронно-променевий плазмовий метод (AIP).

Фізичні принципи, закладені в основу методу AIP, дозволяють найбільш повно вирішити проблему реалізації в покритті заданого хімічного і фразового складу матеріалу (і як окремий випадок - відтворення складу розпилюємої мішені), а також забезпечення необхідної щільності або пористості шару, що наноситься.

Застосування вакуум-плазмових методів до проблеми створення матеріалів для тонкоплівкових SOFC дозволяє забезпечити легко досягаємі і регульовані умови синтезу осаджуваних хімічних сполук і механічну міцність покриттів [8-12].

3 використанням методу атомно-іонного плазмового розпилення (AIP) розроблені технології отримання тонких газощільних покриттів електроліту ВCN і пористих електродних (анодного і катодного) шарів для виготовлення дослідних елементів SOFC. 
Дослідження, виконані на BCN зразках (рис. 5), свідчать про гарну відтворюваність хімічного і фразового складу мішені в покритті з $\mathrm{BaCeNdO}_{3}$. Дослідження зламів зразків 3 електродними покриттями 3 використанням растрової мікроскопії свідчить про хорошу адгезію між основою з BCN i нанесеними покриттями.

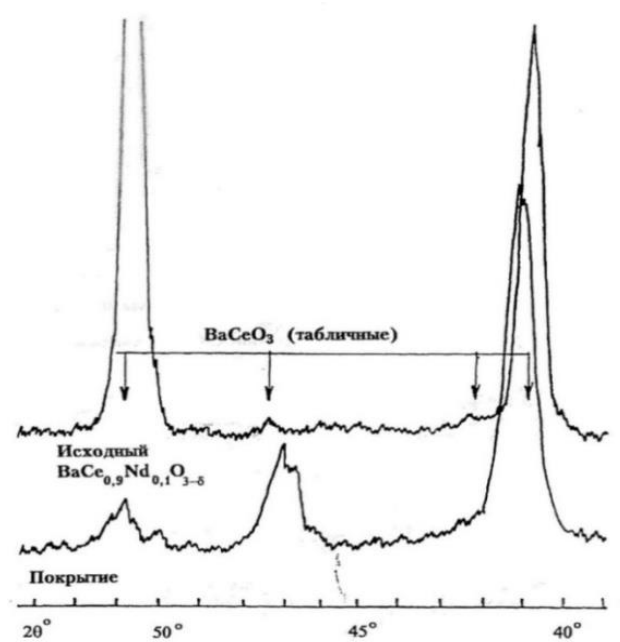

a

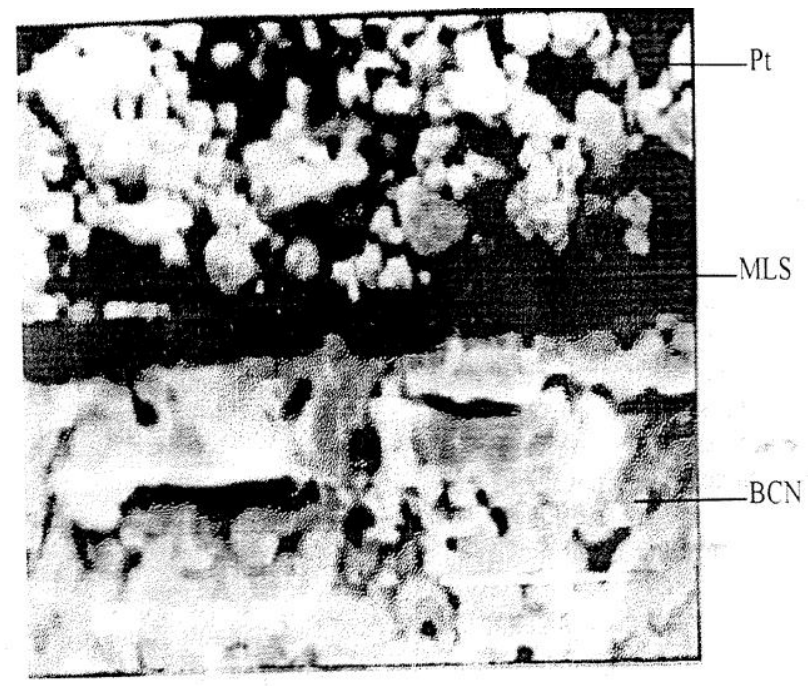

6

Рис. 5. Дослідження BCN зразків: (а) - порівняльні дифракційні спектри BCN в покриттях і розпилюємих мішенях; (б) - растрова мікроскопія зламу дослідного зразка(BCN (основа) - MLS (покриття) - Pt (впечена паста), х3300).

Розроблено технології отримання струмознімальних нікелевих і нікельхромових покриттів для дослідних елементів SOFC на основі електроліту BCN 3 використанням методу вакуум-дугового розпилення (табл. 1), що забезпечують отримання струмознімальних покриттів з заданим рівнем характеристик по товщині, складу, адгезії, мікротвердості і прийняті в якості базових в розробках по створенню плівкових композицій SOFC.

Таблиця 1

\begin{tabular}{|c|c|c|c|c|}
\hline № & $\begin{array}{c}\text { Матеріал паливного } \\
\text { токоз'єму }\end{array}$ & $\begin{array}{c}\text { Ширина токоз'ємного } \\
\text { елемента, мм }\end{array}$ & $\begin{array}{c}\text { Товщина, } \\
\text { мкм }\end{array}$ & Кількість \\
\hline 1 & Нікель & 2 & 6 & 2 \\
\hline 2 & Нікель & 4 & 3 & 2 \\
\hline 3 & Нікель & 6 & 2 & 2 \\
\hline 4 & Нікель + Хром & 2 & 6 & 2 \\
\hline 5 & Нікель + Хром & 4 & 3 & 2 \\
\hline 6 & Нікель + Хром & 6 & 2 & 2 \\
\hline
\end{tabular}

Товщина струмознімальних покриттів для нікелевого струмознімача 3,8...4,2 мкм, для нікель-хромового $(4,3 \ldots 4,7)$ мкм, мікротвердість для нікелевих покриттів $1450 \mathrm{MH} / \mathrm{M}^{2}$, для нікель-хромових - $4550 \mathrm{MH} / \mathrm{M}^{2}$. 
Проведено дослідження і розроблені експериментальні технології нанесення тонких шарів електроліту BCN, анодів $\mathrm{Ni}+\mathrm{BCN}$ і струмознімачів з $\mathrm{Ni} \mathrm{i}$ $\mathrm{Ni}+$ Сг вакуум-плазмовими методами (рис. 6).

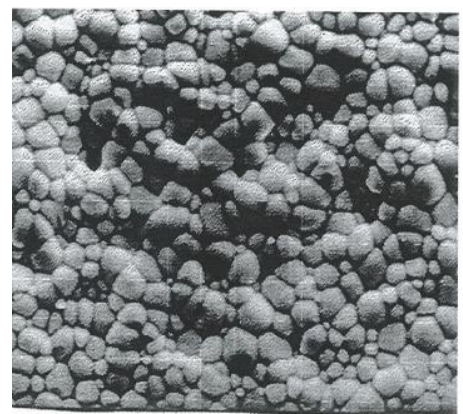

a

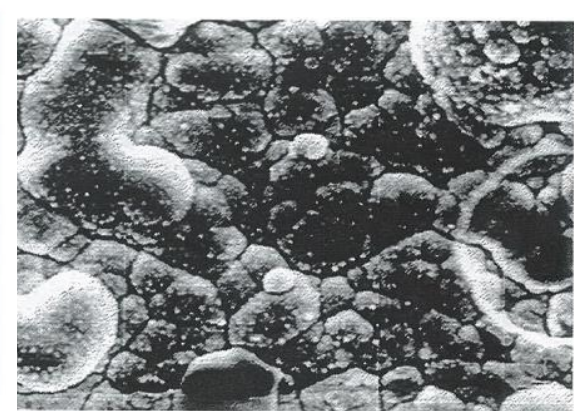

б

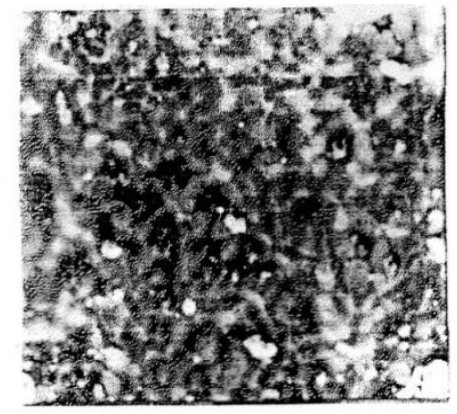

B

Рис. 6. Морфологія поверхні: (а) - електроліта BCN, (б) - шару Ni-BCN, (в) - покриття Ni-Cг на аноді Ni-BCN, x1500.

Проведені стендові випробування виготовлених за розробленими технологіями партій тонкоплівкових ОПЕ.

В температурному інтервалі $(600 \ldots 900)^{\circ} \mathrm{C}$ досліджені електрохімічні характеристики тонкоплівкових одиничних плівкових елементів (ОПЕ) 3 електролітом BCN (робоча площа електроліту $\mathrm{BCN}-3,14 \mathrm{~cm}^{2}$ ) товщиною $(1,7 \ldots 1,9)$ мм, виготовленим методом пресування і наступного спікання, і електродних шарів Ni-BCN $\left(11,4 \mathrm{mr} / \mathrm{cm}^{2}\right)$, MLS $\left(1,1 \mathrm{mr} / \mathrm{cm}^{2}\right)$, виконаних методами атомно-іонного плазмового розпилення і електро-дугового напилення, а також 3 додатковими платиновими струмознімачами (табл. 2).

Таблиця 2

\begin{tabular}{|c|c|c|c|}
\hline \multirow{2}{*}{$\begin{array}{r}\text { Температура } \\
\text { випробувань, }{ }^{\circ} \mathrm{C}\end{array}$} & \multicolumn{3}{|c|}{ OПE Ni-BCN/BCN/MLS+Pt } \\
\hline & $U, \mathrm{~B}$ & $I, \mathrm{MA} / \mathrm{cm}^{2}$ & $\begin{array}{r}P_{\max }, \\
\mathrm{MBT} / \mathrm{CM}^{2}\end{array}$ \\
\hline \multirow{4}{*}{600} & 0,95 & 0 & \multirow{4}{*}{9,5} \\
\hline & 0,593 & 14,1 & \\
\hline & 0,455 & 20,0 & \\
\hline & 0,21 & 31,2 & \\
\hline \multirow{3}{*}{700} & 0,9 & 0 & \multirow{3}{*}{15,3} \\
\hline & 0,677 & 16,5 & \\
\hline & 0,312 & 44,7 & \\
\hline \multirow{4}{*}{800} & 0,842 & 0 & \multirow{4}{*}{21,1} \\
\hline & 0,7 & 16,5 & \\
\hline & 0,584 & 30,3 & \\
\hline & 0,39 & 52,9 & \\
\hline \multirow{4}{*}{900} & 0,81 & 0 & \multirow{4}{*}{26,7} \\
\hline & 0,71 & 16,5 & \\
\hline & 0,61 & 32,9 & \\
\hline & 0,45 & 58,8 & \\
\hline
\end{tabular}


Максимальна потужність, що відбирається від ОПЕ в температурному інтервалі $(600 \ldots 900)^{\circ} \mathrm{C},-27 \mathrm{mBT} / \mathrm{cm}^{2}$.

\section{Висновки}

Досягнутий АТ «ФЕД» рівень розробок тонкоплівкових композиційних матеріалів з використанням іонно-плазмових і плазмохімічних методів створює передумови зміни властивостей по відношенню до традиційних матеріалів на $2 . .3$ і більше порядків, зниження робочої температури до $400 \ldots 600^{\circ} \mathrm{C}$, що дозволить розробляти принципово нові конструкції тонкоплівкових ПЕ (товщиною в 10-20 разів менше, ніж трубчастий варіант) і серійноздатні технології їх виготовлення в наступних напрямках:

- нанесення тонкоплівкових композицій на розроблену конструкцію 3 урахуванням технологічних обмежень для різних методів осадження;

- отримання композиційних матеріалів, що складаються 3 шарів: газощільного електроліту i електродних шарів 3 тонкоплівковими струмознімальними контактами;

- забезпечення поділу газових сумішей керамічним шаром електроліту при товщині < 50...20 мкм;

- мінімізація товщини плівкового електроліту та інших фрункціональних шарів паливної комірки;

- підвищення міцності зчеплення шарів і корозійної стійкості струмознімальних контактів і електродних шарів в робочих середовищах для забезпечення працездатності конструкції протягом всього процесу експлуатації.

\section{Список літератури}

1. Sürer, M. G. State of art of hydrogen usage as a fuel on aviation [Text] / M. G. Sürer, H. T. Arat // European Mechanical Science. - 2018. - Vol. 2, iss. 1. - P. 20-30. doi: 10.26701/ems.364286

2. SOFC-APU systems for aircraft: A review [Text] / M. D. Fernandes, S. D. P. Andrade, V. N. Bistritzki et al. // International Journal of Hydrogen Energy. 2018. - Vol. 43, iss. 33. - P. 16311-16333. doi: 10.1016/j.ijhydene.2018.07.004

3. Solid oxide fuel cell (SOFC); A new approach of energy generation during the pandemic COVID-19 [Text] / S. Afroze, M. S. Reza, Q. Cheok et al. // International Journal of Integrated Engineering. - 2020. - Vol. 12, iss. 5. - P. 245256. doi: 10.30880/ijie.2020.12.05.030

4. Rajashekara, K. Hybrid fuel cell power in aircraft [Text] / K. Rajashekara, J. Grieve, D. Daggett // IEEE Industry Applications Magazine. - 2008. - Vol. 14, iss. 4. - P. 54-60. doi: 10.1109/MIAS.2008.923606

5. Azizi, M. A. Progress in solid oxide fuel cell-gas turbine hybrid power systems: System design and analysis, transient operation, controls and optimization [Text] / M. A. Azizi, J. Brouwer // Applied Energy. - 2018. - Vol. 215. - P. 237-289. doi: 10.1016/j.apenergy.2018.01.098

6. SAE AS 6858. Installation of Fuel Cell Systems in Large Civil Aircraft [Text]. - SAE International, 2017. - 35 p. doi: 10.4271/AS6858

7. SAE AIR 6464. EUROCAE/SAE WG80/AE-7AFC Hydrogen Fuel Cells Aircraft Fuel Cell Safety Guidelines [Text]. - SAE International, 2020. - 42 p. doi: 10.4271/AIR6464

8. Установка Avinit для нанесення багатошарових функціональних 
покриттів [Текст] / А. В. Сагалович, О.В.Кононихін, В.В.Попов та ін. // Физическая инженерия поверхности. - 2010. - Т. 8. - С. 336-347.

9. Экспериментальные исследования покрытий типа Avinit [Текст] / A. B. Сагалович, А. В. Кононыхин, В.В. Попов и др. // Авиационно-космическая техника и технология. - 2011. - № 3. - С. 5-15.

10. Технологічні схеми формування багатошарових покриттів «Avinit» [Текст] / О.В. Сагалович, О.В.Кононихін, В.В.Попов та ін. // Вісник двигунобудування. - 2011. - № 1. - С. 33-45.

11. Experimental research of multicomponent multilayer ion-plasma Avinit coatings [Text] / A. V. Sagalovych, A. V. Kononyhin, V. V. Sagalovych et al. // Физическая инженерия поверхности. - 2012. - Т. 10, № 4. - С. 229-236.

12. Нанесение покрытий на сложнопрофильные прецизионные поверхности газофазным методом (CVD) / А. В. Сагалович, А. В. Григорьев, А. В. Кононыхин и др. // Физическая инженерия поверхности. - 2011. - Т. 9, № 3. - C. 229-236.

\section{References}

1. Sürer, M. G., Arat, H. T. State of art of hydrogen usage as a fuel on aviation. European Mechanical Science, 2018, vol. 2, iss. 1, pp. 20-30. doi: 10.26701/ems.364286

2. Fernandes, M. D., Andrade, S. D. P., Bistritzki, V. N., Fonseca, R. M., Zacarias, L. G., Gonçalves, H. N. C., de Castro, A. F., Domingues, R. Z., Matencio, T. SOFC-APU systems for aircraft: A review. International Journal of Hydrogen Energy, 2018, vol. 43, iss. 33, pp. 16311-16333. doi: 10.1016/j.ijhydene.2018.07.004

3. Afroze, S., Reza, M. S., Cheok, Q., Taweeku, J., Azad, A. K. Solid oxide fuel cell (SOFC); A new approach of energy generation during the pandemic COVID19. International Journal of Integrated Engineering, 2020, vol. 12, iss. 5, pp. 245256. doi: $10.30880 /$ ijie.2020.12.05.030

4. Rajashekara, K., Grieve, J., Daggett, D. Hybrid fuel cell power in aircraft. IEEE Industry Applications Magazine, 2008, vol. 14, iss. 4, pp. 54-60. doi: 10.1109/MIAS.2008.923606

5. Azizi, M. A., Brouwer, J. Progress in solid oxide fuel cell-gas turbine hybrid power systems: System design and analysis, transient operation, controls and optimization. Applied Energy, 2018, vol. 215, pp. 237-289. doi: 10.1016/j.apenergy.2018.01.098

6. SAE AS 6858. Installation of Fuel Cell Systems in Large Civil Aircraft. SAE International, 2017,35 p. doi: $10.4271 /$ AS6858

7. SAE AIR 6464. EUROCAE/SAE WG80/AE-7AFC Hydrogen Fuel Cells Aircraft Fuel Cell Safety Guidelines. SAE International, 2020, 42 p. doi: 10.4271/AIR6464

8. Sagalovich, A. V., $\quad$ Kononikhin, A. V., $\quad$ Popov, V. V., $\quad$ Dudnik, S. F., Sagalovich, V. V. Ustanovka Avinit dlya nanesennya bagatosharovikh funktsional'nikh pokrittiv [Installation Avinit for applying multi-functional coatings]. Fizicheskaya inzheneriya poverkhnosti - Physical surface engineering, 2010, vol. 8, pp. 336-347.

9. Sagalovich, A. V., $\quad$ Kononykhin, A. V., $\quad$ Popov, V. V., $\quad$ Dudnik, S. F., Sagalovich, V. V. Eksperimental'nye issledovaniya pokrytiy tipa Avinit [Experimental studies of Avinit type coatings]. Aviacijno-kosmicna tehnika i tehnologia - Aerospace technic and technology, 2011, vol. 3, pp. 5-15. 
10. Sagalovich, O. V., Kononikhin, O. V., Popov, V. V., $\quad$ Dudnik, S. F., Sagalovich, V. V. Tekhnologichni skhemi formuvannya bagatosharovikh pokrittiv "Avinit» [Technological schemes of formation of multilayer coverings "Avinit"]. Visnik dvigunobuduvannya - Herald of Aeroenginebuilding, 2011, vol. 1, pp. 33-45.

11. Sagalovych, A. V., Kononykhin, A. V., Popov, V. V., Sagalovych, V. V. Experimental research of multicomponent multilayer ion-plasma Avinit coatings. Fizicheskaya inzheneriya poverkhnosti - Physical surface engineering, 2012. vol. 10, no. 4, pp. 229-236.

12. Sagalovich, A. V., Grigor'ev, A. V., Kononykhin, A. V., Popov, V. V., Sagalovich, V. V. Nanesenie pokrytiy na slozhnoprofil'nye pretsizionnye poverkhnosti gazofaznym metodom (CVD) [Coating of complex precision surfaces by the gas phase method (CVD)]. Fizicheskaya inzheneriya poverkhnosti - Physical surface engineering, vol. 9, no. 3, pp. 229-236.

Надійшла до редакції 18.09.2020. Розглянута на редколегії 20.09.2020.

\section{Применение ионно-плазменных методов для получения тонкопленочных топливных элементов}

Новые требования к эксплуатационным системам самолетов, наряду с постоянно растущим требованием снижения расхода топлива, выбросов загрязняющих веществ и шума, в значительной степени способствуют поиску новых более чистых технологий, в которых топливные элементы демонстрируют большой потенциал. В работе продемонстирован достигнутый уровень разработок тонкопленочных композиционных материалов с использованием ионно-плазменных и плазмохимических методов на АО «ФЕД», что позволяет создать предпосылки изменения свойств по отношению к традиционным материалам на 2...3 и більше порядков, снижения рабочей температуры до $400 \ldots 600^{\circ} \mathrm{C}$. Это дает возможность разрабатывать принципиально новые конструкции тонкопленочных топливных элементов (толщиной в 10-20 раз меньше, чем трубчатый вариант) и серийные технологии их изготовления в следующих направлениях: нанесение тонкопленочных композиций на разработанную конструкцию с учетом технологических ограничений для разных методов осаждения; получение композиционных материалов, которые состоят из слоев: газоплотного электролита и электродных слоев с тонкопленочными токосъемными контактами; обеспечение раздела газовых смесей керамическим слоем электролита при толщине < 50...20 мкм; минимизация толщины пленочного электролита и других функциональных слоев топливной каморки; повышение прочности сцепления слоев и коррозийной стойкости токосъемных контактов и электродных слоев в рабочих средах для обеспечения работоспособности конструкции на протяжении всего процесса эксплуатации.

Ключевые слова: тонкопленочный топливный элемент, ионноплазменные методы, самолет, электрическая энергия.

\section{Application of ion-plasma methods to obtain thin-film fuel cells}

New demands on aircraft operating systems, along with ever-increasing demands for reduced fuel consumption, pollutant emissions and noise, are driving 
the search for new cleaner technologies in which fuel cells show great potential. The work demonstrates the achieved level of development of thin-film composite materials using ion-plasma and plasma-chemical methods at JSC FED, which allows creating the prerequisites for changing properties in relation to traditional materials by $2 \ldots 3$ and more orders of magnitude, reducing the operating temperature to $400 \ldots 600$ ${ }^{\circ} \mathrm{C}$. This makes it possible to develop fundamentally new designs of thin-film fuel cells (10-20 times less thick than the tubular version) and serial technologies for their manufacture in the following directions: application of thin-film compositions to the developed structure, taking into account technological limitations for different deposition methods; obtaining composite materials, which consist of layers: gas-tight electrolyte and electrode layers with thin-film current-collecting contacts; ensuring the separation of gas mixtures with a ceramic electrolyte layer with a thickness of < $50 . . .20$ microns; minimizing the thickness of the electrolyte film and other functional layers of the fuel cell; increasing the adhesion strength of layers and corrosion resistance of current-collecting contacts and electrode layers in working environments to ensure the operability of the structure throughout the entire operation process.

Keywords: thin-film fuel cell, ion-plasma methods, aircraft, electrical energy.

\section{Відомості про авторів}

Сагалович Олексій Владиславович - керівник управління спеціальних технологій, АТ «ФЕД», м. Харків, Україна; e-mail: iht@kharkov.ua.

Сагалович Владислав Вікторович - доктор технічних наук, професор, головний технічний керівник, АТ «ФЕД», м. Харків, Україна; e-mail: avinit@avinit.ua.

Попов Віктор Васильович - кандидат технічних наук, голова правління, АТ «ФЕД», м. Харків, Україна; e-mail: fed@fed.com.ua.

Дуднік Станіслав Федорович - кандидат технічних наук, керівник відділу тонких технологій, АТ «ФЕД», м. Харків, Україна; e-mail: dudnik@avinit.ua.

Кононихін Олександр Володимирович - заступник голови правління, АТ «ФЕД», м. Харків, Україна; e-mail: fed@fed.com.ua.

\section{About the Authors}

Sagalovych Oleksiy - Head of Special Technologies Department, JSC "FED", Kharkiv, Ukraine; e-mail: iht@kharkov.ua.

Sagalovych Vladyslav - Doctor of Technical Sciences, Professor, chief technical officer, JSC "FED”, Kharkiv, Ukraine; e-mail: avinit@avinit.ua.

Popov Viktor - Candidate of Technical Sciences, Chairman of the Board, JSC “FED”, Kharkiv, Ukraine; e-mail: fed@fed.com.ua.

Dudnik Stanislav - Candidate of Technical Sciences, Head of Thin Technologies Department, JSC “FED”, Kharkiv, Ukraine; e-mail: dudnik@avinit.ua.

Kononyhin Oleksandr - Deputy Chairman of the Board, JSC "FED”, Kharkiv, Ukraine; e-mail: fed@fed.com.ua. 